\title{
Socioeconomic changes of farmers due to adoption of rice production technologies in selected areas of Sherpur district
}

\author{
M. M. Salehin, M. S. Kabir, K. M. Morshed and K. S. Farid \\ Department of Rural Sociology, Bangladesh Agricultural University, Mymensingh-2202, Bangladesh
}

\begin{abstract}
The study was aimed at finding out the changes occurred in different aspects of socioeconomic conditions of the framers due to adoption of rice production technologies. For the present study data were collected from 90 randomly selected farmers in three villages of Gourdwer union under Nakla upazila of Sherpur district with the help of interview schedule. Correlation and t-test were used to ascertain the relationship between the concerned dependent and independent variables. Findings revealed that about 51 percent of the farmers had medium adoption while 33 percent had high adoption of rice production technologies. Correlation analysis indicates that education, annual income showed significant positive relationships, and age and family size of the farmers showed significant negative relationships with their adoption of rice production technologies. Besides farm size did not show any significant relationship with their adoption. Findings also showed a significant increase in annual income (from Tk.88.82 thousand to Tk.109.26 thousand), food consumption expenditure (from Tk.17.35 thousand to Tk.20.41 thousand), housing environment (scores rose to 14.22 from 7.82) and family status of the framers (scores increased from 19.46 to 27.82). The differences between before and after changes in income, expenditure, housing environment score and family status score were statistically significant.
\end{abstract}

Keywords: Rice production technology, Adoption, Socioeconomic changes

\section{Introduction}

Bangladesh has experienced a severe price hike especially in case of rice in 2008. Through attaining self reliance in food production and thus achieving a concrete food security a country like Bangladesh can move toward its ultimate goal of economic development. Nevertheless, in the context of constant high population growth (1.5 percent) (BBS, 2007) intensive food supply through rice production is one of the solutions to food security. Agriculture being one of the major sectors of production in Bangladesh, contributes about 19.61 percent of gross domestic product (GDP) and occupies 51.7 percent of the labor force (BBS, 2007). Rice was central to Bangladesh's economy and agriculture. Rice accounted for nearly 18 percent of the national GDP and provided about 70 percent of an average citizen's total calorie intake. Rice area totaled about 10 million ha, and accounted for 75 percent of the total cropped area and 93 percent of total area under cereals (IRRI, 2008). The rice sector was by far the most important provider of rural employment.

Recently, the main objectives of the Government's agricultural policy emphasize on increasing food supplies for the bulging population as well as providing income generative sources for rural people. As there has not a single unit of productive arable land left, in order to achieve those national goals we have to adopt some modern advanced technologies to boost up the present agricultural output. This may be carried out through increased cropping intensity, providing appropriate time oriented irrigation facilities, wide spread incorporation of modern high yielding varieties (Deb et al, 1991; Jabber and Alam, 1993), applying the judicial and efficient doses of organic and balanced synthetic fertilizers and finally the incorporation of IPM techniques (Reddy and Reddy, 2002; Bakker et al, 2001). This piece of study is conducted to find out the feasible and efficient rice production technologies in regards of basic economic condition of Bangladesh and along with that to figure out the recent trend of farmers' attitude and frequency of adoption of technology in their fields.

The success of any technology depends on its dissemination among the potential users, which ultimately is measured by the level of adoption of that technology (Reddy and Reddy, 2002). It is assumed that notable improvements can take place in Bangladesh agriculture, if the available technologies are accepted and adopted by the farmers. For this reason, this study was conducted to gain an understanding on the adoption of rice production technologies by the farmers and the changes occurred in different aspects of socioeconomic condition of the farmers. The general objective of the research was to determine the level of adoption of rice production technology and its impact on the socioeconomic condition of the farmers. However, the specific objectives were to find out the changes occurred in different aspects of socioeconomic condition of the farmers due to adoption of rice production technologies, and to examine the relationship of technology adoption and socioeconomic changes of farmers with their selected characteristics. 


\section{Methods and Materials}

\section{Population and sampling design}

An up to date list of all farm family heads using only modern rice production technologies of the selected villages was prepared with the help of Sub Assistant Agricultural Officer (SAAO). The list comprised a total of 900 farmers which constituted the population of this study. In the present study random sampling was followed. Approximately 10 percent of the rice growers from the population were selected from study area by using a table of random number (Fisher and Yates, 1963). Thus, the sample size for Lava was 28, Gourdwer was 39 and Runigai was 23 making the total sample size of 90 farmers (Table 1).

Table 1. Distribution of population and sample respondents in three selected villages of Nakla Upazila

\begin{tabular}{clcc}
\hline SL & Name of the villages & $\begin{array}{c}\text { Total number of farmers (used } \\
\text { technology) }\end{array}$ & $\begin{array}{c}\text { Sample farmers } \\
\text { (No.) }\end{array}$ \\
\hline No. & Lava & 280 & 28 \\
2 & Gourdwer & 390 & 39 \\
3 & Runigai & 230 & 23 \\
\hline Total & & 900 & 90 \\
\hline
\end{tabular}

\section{Methods of data collection}

The survey method was followed in the present study. It is argued that the method is comparatively less costly, less time consuming, easier to employ and most appropriate for data collection from the farms. Data were collected by using a structured interview scheduled. Before preparing and applying the schedule, the researcher communicated with the Agricultural Officer of Nakla, concerned SAAO's, educated persons and local leaders of the study area.

\section{Measurement of independent variable}

Age: Age of the respondent farmer was measured by counting the actual years from birth to the time of interview on the basis of the respondent's statement.

Education: To measure education, a score of 1 was assigned for each year of schooling. Family size: Family size was operationally measured by assigning a score of 1 for each member of the family who jointly lived and ate together.

Farm size: The following formula was used to measure the farm size (in hectare):

Farm size: $\left.A_{1}+A_{2}+1 / 2\left(A_{3}+A_{4}\right)+A_{5} \times 0\right)+A_{6}+A_{7}+A_{8}+A_{9}$, where $A_{1}, A_{2}, A_{3}, A_{4}, A_{5}, A_{6}, A_{7}, A_{8}$, and $A_{9}$ are respectively homestead area, own cultivable land, rented out, rented in, mortgaged out, mortgaged in, pond and homestead garden.

Annual income: Yearly earnings from farming and other sources were added to obtain total family annual income of a respondent. A unit score of one was taken for each thousand taka.

Measurement of dependent variable

The adoption of rice production technologies by the farmers was measured by using the following formula as developed by Bose (1965).

Adoption of rice production technologies index $=\frac{\sum e / p}{P S} \times 100$

Where, $\mathrm{e}=$ Extent of adoption of rice production technologies in a particular land in a particular year, $\mathrm{p}=$ Potentiality of rice production technologies in a particular land in a particular year and Ps = Period under study of rice production technologies (For this study it is two years).

In this study, rice production technologies adoption index was expressed in percentage. Hence, the rice production technologies adoption index of a farmer could range from 0 to 100, where, "0" indicates no adoption and "100" indicated highest adoption. 


\section{Measurement of family status}

Family status was measured on the basis of the extent of change occurred in four selected dimensions such as change in education, family structure, decision making and access to health care facilities. These four dimensions had two situations - 'before' and 'after'. All before and after situation scores had been added together separately. Finally change in family status score was measured by computing 'before' and 'after' situation.

\section{Results and Discussion}

\section{Socioeconomic characteristics of the sample farmers}

A number of socioeconomic aspects of the sample households were examined. These were age, level of education, family size, farm size and annual income. Distribution of the farmers according to their different characteristics has been presented in Table 2 .

Table 2. Independent and dependent variable characteristics profile

\begin{tabular}{|c|c|c|c|c|c|c|c|c|}
\hline SI No. & Characteristics & $\begin{array}{c}\text { Measure } \\
\text { ment }\end{array}$ & $\begin{array}{c}\text { Possible } \\
\text { range }\end{array}$ & $\begin{array}{c}\text { Observed } \\
\text { range }\end{array}$ & Categories & $\begin{array}{c}\text { Respondent } \\
(\%)\end{array}$ & Mean & SD \\
\hline 1. & Age & \begin{tabular}{|l} 
Actual \\
years
\end{tabular} & Unknown & $30-62$ & $\begin{array}{l}\text { Young aged (up to } 35) \\
\text { Middle aged (36-50) } \\
\text { Old aged (51 and above) }\end{array}$ & $\begin{array}{l}24 \\
54 \\
22\end{array}$ & 42.71 & 8.87 \\
\hline 2. & $\begin{array}{l}\text { Level of } \\
\text { education }\end{array}$ & $\begin{array}{l}\text { Rated } \\
\text { score }\end{array}$ & Unknown & $0-12$ & $\begin{array}{l}\text { No education }(0) \\
\text { Can sign only (0.5) } \\
\text { Primary education (1-5) } \\
\text { Secondary education (6-10) } \\
\text { Above secondary education (11 } \\
\text { and above) }\end{array}$ & $\begin{array}{c}7 \\
13 \\
28 \\
25.5 \\
26.5\end{array}$ & 6.44 & 4.84 \\
\hline 3. & Family size & $\begin{array}{l}\text { Rated } \\
\text { score }\end{array}$ & Unknown & $4-11$ & $\begin{array}{l}\text { Small family (up to } 4 \text { ) } \\
\text { Medium family (5-7) } \\
\text { Large family ( } 8 \text { and above) }\end{array}$ & $\begin{array}{l}22 \\
41 \\
37\end{array}$ & 6.09 & 1.83 \\
\hline 4. & Farm size & $\begin{array}{l}\text { Actual } \\
\text { (in ha) }\end{array}$ & Unknown & $\begin{array}{l}0.453- \\
5.465\end{array}$ & $\begin{array}{l}\text { Small farm (up to } 0.99 \text { ha) } \\
\text { Medium Farm (1-2.99 ha) } \\
\text { Large farm (3.00 and ha) }\end{array}$ & $\begin{array}{l}20 \\
67 \\
13 \\
\end{array}$ & 1.78 & 1.11 \\
\hline 5. & Annual income & $\begin{array}{l}\text { Comput } \\
\text { ed score }\end{array}$ & Unknown & $45-350$ & $\begin{array}{l}\text { Low (up to } 70.00 \text { thousand) } \\
\text { Medium ( } 70.10-130.00 \text { thousand) } \\
\text { High (130.00 thousand and } \\
\text { above) }\end{array}$ & $\begin{array}{l}40 \\
43 \\
17\end{array}$ & 112.20 & 79.67 \\
\hline 6. & $\begin{array}{l}\text { Adoption of } \\
\text { rice production } \\
\text { technologies }\end{array}$ & $\begin{array}{l}\text { Rated } \\
\text { score }\end{array}$ & $37.03-55$ & $0-100$ & $\begin{array}{l}\text { Low (up to } 41 \%) \\
\text { Medium (41.01 to } 48.99 \% \text { ) } \\
\text { High ( } 49 \text { and above) }\end{array}$ & $\begin{array}{l}16 \\
51 \\
33\end{array}$ & 45.35 & 3.74 \\
\hline
\end{tabular}

The highest proportion (54 percent) of the respondents fell in the middle-aged category compared to (24 percent) young and (22 percent) old aged category. A large proportion (28 percent) of the respondents fell under the category of "primary education" compared to 26.5 percent "higher secondary education", 25.5 percent having "secondary education". The finding indicates that educated individual is likely to be more receptive to the modern facts and ideas; they have much mental strength in deciding on a matter related to problem solving or adoption of technologies in their everyday life. In the study areas more than 78 percent of the respondents had either medium or large family size. The data indicate that the average family size (6.09 percent) of the respondents of the study area was higher than the national average of 5.4 (BBS, 2007). Majority (87 percent) of the farmers had either small or medium farms. The average farm size of the respondent farmers was 1.78 hectares. Highest proportion (43 percent) of the respondents had medium annual income compared to (32 percent) having low income group and (25 percent) under high income group. Thus, the overwhelming majority (68 percent) of the respondents had medium to high family income. The average income of the farmers of the study area is much higher than the average per capita income of the country i.e. 387 U.S. dollar (BBS, 2001). 


\section{Adoption of rice production technologies}

The adoption of rice production technologies of the respondents ranged from 37.03 to 55 against the possible range of 0 to 100 . The average adoption was 45.36 with a standard deviation 3.74 based on the adoption scores, the respondents were classified into three categories: "low adoption" (up to 41 percent), "medium adoption" (41.01-48.99 percent), and "high adoption" (49 and above percent). The distribution of respondents according to their adoption of rice production technologies has been shown in Table 2 . The highest proportion (51 per cent) of the farmers fell under the medium adoption category, while 33 percent had high adoption and 16 per cent had low adoption.

\section{Relationship between characteristics and technology adoption by the farmers}

Age of the farmers had a significant negative relationship with their adoption of rice production technologies. The relationship between concerned variables was low. This finding indicates that the less is the age of the farmers the more was their adoption of rice production technologies. Thus, it could be said that young farmers had favorable tendency to adopt rice production technologies. On the other hand, the findings indicate that education of the farmers had a significant and positive relationship with their adoption of rice production technologies. The farmers, who have higher education likely to have higher adoption of rice production technologies.

Table 3. Co-efficient of correlation of the selected characteristics of respondent farmers and their adoption of rice production technologies

\begin{tabular}{|c|c|c|c|c|}
\hline \multirow[t]{2}{*}{ Dependent variable } & \multirow[t]{2}{*}{$\begin{array}{l}\text { Independent } \\
\text { variable }\end{array}$} & \multirow[t]{2}{*}{$\begin{array}{l}\text { Compared value } \\
\text { of "r" }\end{array}$} & \multicolumn{2}{|c|}{$\begin{array}{c}\text { Table value of "r" at } 88 \\
\text { degree of freedom }\end{array}$} \\
\hline & & & 0.05 & 0.01 \\
\hline \multirow{5}{*}{$\begin{array}{l}\text { Adoption of rice production } \\
\text { technologies }\end{array}$} & Age & $-.244^{\star}$ & \multirow{5}{*}{0.211} & \multirow{5}{*}{0.275} \\
\hline & Education & $.232^{\star}$ & & \\
\hline & Family size & $-.255^{\star}$ & & \\
\hline & Farm size & $.063 \mathrm{NS}$ & & \\
\hline & Annual income & $.278^{\star \star}$ & & \\
\hline
\end{tabular}

Note $\quad$ NS $=$ Not Significant

* Correlation is significant at 0.05 level of probability

${ }^{* *}$ Correlation is significant at 0.01 level of probability

Family size of the farmers had negative significant relationship with their adoption of rice production technologies. Findings mentioned above indicate that farmers' having large family size were less responsive to the adoption of rice production technologies.

One of the important findings suggests that farm size of the farmers had no significant relationship with their adoption of rice production technologies. Therefore it was concluded that annual income of the farmers had a positive significant relationship with their adoption of rice production technologies.

The findings indicate that with the increase of annual income, there was corresponding increase of adoption of rice production technologies. The finding is quite logical, because rice production technologies are costly. Thus, availability of money is more essential to solve the financial inconveniences of the farmers to a considerable extent.

\section{Socioeconomic changes due to adoption of rice production technology}

For measuring the impact of technology adoption on the socioeconomic conditions of the respondents before adoption were compared with their present condition. After adopting rice production technologies, the socioeconomic condition of the respondents was changed significantly. 
The income difference of the respondent households ranged from Tk.9.00 to Tk. 50.00 thousand with an average of Tk. 20.44 thousand and standard deviation 9.94. On the basis of the income difference, the respondents were classified into three categories as shown in Table 4.

Table 4. Salient features of the changes due to adoption of rice production technologies

\begin{tabular}{|c|c|c|c|c|c|}
\hline \multirow[t]{2}{*}{ Indicates parameter } & \multirow[t]{2}{*}{ Dimension of adoption of technologies } & \multicolumn{2}{|c|}{ Respondents } & \multirow[t]{2}{*}{ Mean } & \multirow{2}{*}{$\begin{array}{l}\text { Standard } \\
\text { deviation }\end{array}$} \\
\hline & & No. & Percent & & \\
\hline \multirow[t]{3}{*}{ Change in income } & Low income difference (up to 14 thousand) & 22 & 24 & \multirow{3}{*}{20.44} & \multirow{3}{*}{9.94} \\
\hline & Medium income difference (15-45 thousand) & 62 & 69 & & \\
\hline & High income difference (46 and above) & 6 & 7 & & \\
\hline \multirow{3}{*}{$\begin{array}{l}\text { Change in food } \\
\text { consumption } \\
\text { expenditure }\end{array}$} & Low expenditure difference (upto2.99 thousand) & 31 & 34 & \multirow[b]{3}{*}{3.05} & \multirow[b]{3}{*}{1.07} \\
\hline & Medium expenditure difference (3-4 thousand) & 50 & 56 & & \\
\hline & High expenditure difference (5 and above) & 9 & 10 & & \\
\hline \multirow{3}{*}{$\begin{array}{l}\text { Change in housing } \\
\text { environment }\end{array}$} & Low housing environment score (up to 3 score ) & 38 & 42 & \multirow[b]{3}{*}{6.40} & \multirow[b]{3}{*}{7.39} \\
\hline & Medium housing environment score (4-18) & 45 & 50 & & \\
\hline & High housing environment score (above 18 score) & 7 & 8 & & \\
\hline \multirow{3}{*}{$\begin{array}{l}\text { Changes in family } \\
\text { status }\end{array}$} & Low family status score (up to 6 score) & 20 & 22 & \multirow{3}{*}{8.2} & \multirow{3}{*}{2.97} \\
\hline & Medium family status score (7-11 score) & 54 & 60 & & \\
\hline & High family status score (above 11 score) & 16 & 18 & & \\
\hline
\end{tabular}

The highest proportion (69 percent) of the respondents had medium income difference compared to 24 percent low income difference. Only 7 percent of the respondents had high income difference. This indicates that the study group was heterogeneous in terms of income difference. The highest proportion (56 percent) of the respondents' had medium food consumption expenditure difference compared to 34 per cent low food consumption expenditure difference. Only 10 per cent of the respondents' had high food consumption expenditure difference. Farmers' income they can spend more money for their livelihood and inflation also rises. Similarly the highest proportion (50 percent) of the respondents had medium housing environment score difference compared to 42 percent low housing environment score difference. Only 8 percent of the respondents had high housing environment score difference. This indicates that the study group was heterogeneous in terms of housing environment score difference is concerned.

The findings regarding housing unit of the respondents before and after adoption of rice production technologies have been shown in Table 5.

Table 5. A summary statement showing categories and salient features of housing environment

\begin{tabular}{|c|c|c|c|c|c|c|c|c|}
\hline \multirow{2}{*}{$\begin{array}{l}\text { Change in } \\
\text { housing } \\
\text { environment }\end{array}$} & \multirow[t]{2}{*}{ Types of changes } & \multicolumn{2}{|c|}{ Number } & \multicolumn{2}{|c|}{ Percentage } & \multicolumn{2}{|c|}{ Average } & \multirow{2}{*}{\begin{tabular}{|c|}
$\begin{array}{c}\text { Percentage } \\
\text { change }\end{array}$ \\
\end{tabular}} \\
\hline & & $\begin{array}{l}\text { Before } \\
(2 \mathrm{yr})\end{array}$ & $\begin{array}{l}\text { After } \\
(2 \mathrm{yr})\end{array}$ & Before & After & Before & After & \\
\hline & Types of housing unit & & & & & & & \\
\hline \multirow{4}{*}{$\begin{array}{l}\text { Change in } \\
\text { housing unit }\end{array}$} & Kacha ghar with straw roof & 57 & 15 & 63.33 & 16.67 & - & - & -73.67 \\
\hline & Kacha ghar with tale roof & 0 & 0 & 0 & 0 & 0 & 0 & 0 \\
\hline & Kacha ghar with tin roof & 30 & 65 & 33.33 & 72.22 & - & - & 116.68 \\
\hline & Half building & 3 & 10 & 3.33 & 11.11 & - & - & 233.63 \\
\hline \multirow{3}{*}{$\begin{array}{l}\text { Change in toilet } \\
\text { condition }\end{array}$} & Bushes or open place & 70 & 15 & 77.78 & 16.67 & - & - & -58.57 \\
\hline & Kacha toilet & 15 & 55 & 16.67 & 61.11 & - & - & 266.58 \\
\hline & Half sanitary toilet & 5 & 20 & 5.55 & 22.22 & - & - & 300.36 \\
\hline \multirow{3}{*}{$\begin{array}{l}\text { Change in } \\
\text { source of } \\
\text { drinking water }\end{array}$} & Water from river or pond & 0 & 0 & 0 & 0 & 0 & 0 & 0 \\
\hline & Others' tube-well & 74 & 40 & 82.22 & 44.44 & - & - & -45.95 \\
\hline & Own of tube-well & 16 & 50 & 17.78 & 55.56 & - & - & 212.48 \\
\hline \multirow{3}{*}{$\begin{array}{l}\text { Change in } \\
\text { family asset } \\
\text { (score) }\end{array}$} & $\begin{array}{l}\text { Low asset possession (up to } \\
15 \text { score) }\end{array}$ & 62 & 52 & 68.89 & 57.78 & \multirow{3}{*}{12.10} & \multirow{3}{*}{17.47} & \multirow{3}{*}{44.38} \\
\hline & $\begin{array}{l}\text { Medium asset possession } \\
(16-30)\end{array}$ & 27 & 29 & 30 & 32.22 & & & \\
\hline & $\begin{array}{l}\text { High asset possession } \\
\text { (above } 30 \text { score) }\end{array}$ & 1 & 9 & 1.11 & 10 & & & \\
\hline Total & & 90 & 90 & 100 & 100 & & & \\
\hline
\end{tabular}


After adoption of rice production technologies 16.67 percent respondents have kacha Ghar with straw roof and in percentage 73.67 percent change was occurred, 72.22 percent respondents have Kacha Ghar with tin roof and in percentage 116.68 percent change was observed and 11.11 percent respondents have half building and in percent 233.63 percent change took place. There was no Kacha Ghar with 'tale' roof before and after adoption of rice production technologies. This indicates that the respondents' housing unit had increased after adopting rice production technologies.

The information reveals that 16.67 percent family did use Kacha toilet before adoption of technologies. After adoption still 61.11 percent respondents families are now using Kacha toilet. On the other hand, 22.22 percent respondents' families are using half sanitary toilet but before adoption of technologies only 5.55 percent respondents used the half sanitary toilet. This indicates that toilet facilities of the respondents were increased because of their increased income and awareness about health care.

About two-thirds (66.67 percent) of the respondent families depend on others' tube well for drinking water before adoption of rice production technologies, on the other hand, after adoption of technologies 50 percent respondent families depend on others tube well for drinking water. Before adoption 33.33 percent of the respondent families used own tube well for drinking water while after adoption 61.11 percent respondent families used own tube well for drinking water. This indicates that a source of drinking water was improved due to adoption of technologies. In the study area no body used river or pond water for drinking before and after adoption of rice production technologies.

\section{Comparative change pattern due to adoption of rice production technologies}

An attempt was made to compare the significant changes in relation to income, food consumption, housing environment and family status of the respondents' families after adoption of rice production technologies. The data in this connection are furnished in Table 6.

Table 6. Difference between "before" and "after' adoption of rice production technologies in some of its selected factors

\begin{tabular}{|c|l|c|c|c|c|}
\hline SI. No & \multicolumn{1}{|c|}{ Variables } & After (2 yr.) & Before (2 yr.) & $\%$ Change & $\begin{array}{c}\text { Observed t-value } \\
\text { with 89 df }\end{array}$ \\
\hline 1 & Income (Thousand) & 109.26 & 88.82 & 24.71 & $19.51^{\star \star}$ \\
\hline 2 & $\begin{array}{l}\text { Food consumption expenditure } \\
\text { (Thousand Taka) }\end{array}$ & 20.41 & 17.35 & 16.86 & $26.98^{\star \star}$ \\
\hline 3 & Housing environment & 14.22 & 7.82 & 81.84 & $8.21^{\star \star}$ \\
\hline 4 & Family status & 27.82 & 19.46 & 42.96 & $27.26^{\star \star}$ \\
\hline
\end{tabular}

Critical value of $\mathrm{t}(0.01)=2.35 \mathrm{df}=89$

** Significant at 0.01 level of probability

The calculated 't' value for the income difference between 'before' and 'after' adoption of rice production technologies was 19.76 , which was highly significant at 0.01 level (Table 6). The result showed a positive change between the before and after income. Hence, it was concluded that income of the respondents after adoption of technologies increased significantly.

In case of food consumption expenditure, the computed value of ' $t$ ' was found to be greater than the tabulated value of ' $t$ ' $=2.35$ with $89 \mathrm{df}$ at 0.01 level of probability (Table 6). Thus, the change in food consumption expenditure between 'before' and 'after' adoption of rice production technologies was statistically significant at 0.01 level of probability. The result showed a positive change between the 'before' and 'after' food consumption expenditure. Hence, it may be concluded that food consumption expenditure of the respondents after adoption of rice production technologies has changed positively and significantly.

Moreover, the calculated value of ' $t$ ' in case of housing environment of the respondents after adoption of technologies was found to be 8.21 as shown in the Table 6 . The computed value of ' $t$ ' was found to be greater than the tabulated value of $t=2.35$ with $89 \mathrm{df}$ at 0.01 level of probability. The change between 'before' and 'after' housing environment was statistically significant at 0.01 level of probability. The result showed a positive change between the 'before' and 'after' housing environment. Hence, it may be concluded that housing environment of the respondents after adoption of technologies was significantly better. 
Finally, the calculated value of ' $\mathrm{t}$ ' in case of family status of the respondents after adoption of technologies was found to be 27.26 as shown in the Table 6 . The computed value of ' $t$ ' was found to be greater than the tabulated value of $\mathrm{t}=2.35$ with $89 \mathrm{df}$ at 0.01 level of probability. The change between 'before' and 'after' family status was statistically significant at 0.01 level of probability. The result showed a positive change between the 'before' and 'after' family status. Hence, it may be concluded that family status of the respondents after adoption of technologies was significantly better.

\section{Conclusion}

Finding of the study and the logical interpretation of their meaning in the light of other relevant facts promoted to conclude that the adoption of rice production technologies by the farmers was more or less satisfactory, as nearly as 84 percent of the farmers had medium or high adoption. Due to adoption of rice production technologies, yearly income, food consumption expenditure of the farmers has increased. At the same time housing environment has significant improvement after adoption of rice production technologies. In the study area changes in the family status which is associated with income and other socioeconomic correlates of the farmer have occurred due to adoption of new technologies in rice production. However to meet the overgrowing demand of food, nutrition and environmental problems, there is a need to enhance the rate further and extent of adoption of rice production technologies among the farmers. Particularly, both the GOs and NGOs worker should provide appropriate technical and management related information to all farmers thorough continued improvements in extension and other support services.

\section{References}

Bell, M.A. et al. 2000. Rice quality management - Principles and some lessons. In G.I. Johnson, Le Van To, Nguyen Duy Doc, and M.C. Webb (Eds.). Quality Assurance in Agricultural Produce. ACIAR Proceedings No. 100, ACIAR, Canberra.

Bangladesh Bureau of Statistics. 2007. Statistical Pocket Book of Bangladesh 2006. Dhaka, Ministry of Planning.

Deb, U. and Mandal M.S. 1991. Impact of New Technology on Production Viability in Bangladesh Agriculture. Bangladesh Journal of Agril. Econ., 14(2):53-61.

FAO. 2004. Food outlook No. 4. Rome, Italy, Economic and Social Department, Food and Agricultural Organization of the United Nations.

Fisher, R.A. and Yates, F. 1963. Statistical table for biological, agriculture and medical research. London, Oliver and Boyed.

Jabber, M.A. and Alam, M.S. 1993. Adoption of Modern Rice Varieties in Bangladesh. Bangladesh Journal of Agril. Econ., 16(2): 7795.

Reddy, G.R. and Reddy, S.J. 2002. Extent of adoption of paddy technologies by the different selected enterprise farmers. Journal of Research ANGRAU, 30(2), 74-88.

International Rice Research Institute. 2008. Facts about Cooperation: Bangladesh and IRRI. Available at http://www.irri.org/media/facts/pdfs/BANGLADESH.pdf accessed on12.08.2008. 